\title{
Chapter 18 \\ Self-development Through \\ Service-Oriented \\ Stress-Adaption-Growth (SOSAG) \\ Process in the Engagement \\ of Computational Thinking Co-teaching \\ Education
}

\author{
Mani M. Y. Wong, Ron C. W. Kwok, Ray C. C. Cheung, Robert K. Y. Li \\ and Matthew K. O. Lee
}

\begin{abstract}
In this chapter, we propose the service-oriented stress-adaption-growth (SOSAG) process based on the existing intercultural transformation theory (ITT), through the engagement of cross-institutional tertiary students in computational thinking (CT) education at primary schools. Students from tertiary education institutions in Hong Kong are recruited, trained, and assessed to become qualified teaching assistants (TAs) for providing in-school co-teaching support in CT education in 32 primary schools. TAs are monitored and dispatched to different years and different classrooms in multiple regions in Hong Kong. Through service engagement, and the proposed service-oriented stress-adaption-growth (SOSAG) process, each TA has to undergo self-development in multiple stages, including pre-assessment, training, teaching practice, and in-class co-teaching. We summarize the ongoing challenges and future directions of SOSAG in this chapter.
\end{abstract}

Keywords Computational thinking $\cdot$ Teaching assistant $\cdot$ Co-teaching $\cdot$ Stress-adaption-growth $\cdot$ Service-oriented $\cdot$ Service learning $\cdot$ Intercultural transformation theory

M. M. Y. Wong · R. C. W. Kwok $(\varangle)$ · R. C. C. Cheung · R. K. Y. Li · M. K. O. Lee City University of Hong Kong, Hong Kong, China

e-mail: isron@cityu.edu.hk

M. M. Y. Wong

e-mail: mani.w@cityu.edu.hk

R. C. C. Cheung

e-mail: r.cheung@cityu.edu.hk

R. K. Y. Li

e-mail: Robert.Li@cityu.edu.hk

M. K. O. Lee

e-mail: ismatlee@cityu.edu.hk

(C) The Author(s) 2019

S.-C. Kong and H. Abelson (eds.), Computational Thinking Education,

https://doi.org/10.1007/978-981-13-6528-7_18 


\subsection{Introduction}

Programming and computing-related skills are vital in the information age both for personal and social development. In CoolThink@ JC, City University of Hong Kong (CityU) aims to provide professional education support to enhance programming literacy among Hong Kong citizens through a series of elaborative teaching and learning activities, in particular targeting the primary school student group in the Hong Kong population.

Programming/coding has now become a global initiative in multiple countries, such as the "Hour of Code" campaign was first initialized by Code.org in the US in 2013 providing free educational resources for all ages. Now, over 100 million students worldwide have already tried an "Hour of Code". In the UK and Australia, programming has been put into the primary education curriculum. In Hong Kong, CityU Apps Lab (CAL) (http://appslab.hk) is a leading University organization offering free workshops to the public to learn to code, and officiated the first "hour of code" in the territory. Over 2,000 h of programming has been achieved in the previous "Hour of Code HK" workshops, and we, at CityU of Hong Kong, have offered over $10,000 \mathrm{~h}$ of programming lessons to the beneficiaries by running "We Can Code" and "Go Code 2015" with the Sino Group.

In the world's major economies, students from elementary to postgraduate level are getting increasingly involved in understanding the fundamentals of computer programs and programming skills. In the UK, a new version of the relevant curriculum was established a year earlier on July 8, 2013 by GOV.UK, putting a significant emphasis on computing skills. The new curriculum replaces basic word processing skills with more demanding tasks such as programming and understanding algorithms. Primary school children are proposed to be taught how to write simple programs using computer languages.

In Singapore, Hong Kong's Asian competitor of diverse areas is a plan being fermented by the INFOCOMM Development Authority (IDA), which prescribes the progressive introduction of software programming classes into public schools. This would provide students with a unique opportunity to write programs in classroom settings employing the teaching and educational resources, which are available to other fundamental curricula. A talk is now being initiated by the nation's Ministry of Education regarding the necessity of incorporating programming into its national curriculum.

Estonia is beyond all doubt taking the lead in programming skill education by launching a nationwide scheme to teach school kids from the age of seven to nineteen the methodology of writing computer programs. It is one of the first countries to have a government that was fully enabled. The ProgeTiger initiative was started in January 2012 by the Estonian government, aiming at bringing programming into classrooms to help raise Estonia's technical competency. This small country with a population of 1.3 million is the home of Skype and has been attracting sponsoring activities from well-known organizations such as the Mozilla Foundation. 
It is of great significance that Hong Kong citizens could grasp the basic principles of mechanisms of the digital devices that play such a large role in modern life and be aware of the fundamentals of programming. It is also important to know that when running the "Hour of Code HK" Campaign, we observe that youth group can achieve the programming tasks in a much shorter time when compared with University students or adults. In this connection, it is identified that there is still a lack of momentum in Hong Kong in the present day to catch up with the world's best.

We believe that students at their early age are able to understand and acquire computational thinking skill at a faster pace; therefore, in this project, we provide the students in the participating schools three years of in-class training and out-of-class mentoring support from junior, intermediate, up to advanced level. For the in-class training at each level, there are 8-14 lessons with each lasting around 35-45 min. The out-of-class mentoring support is provided by our university student mentors on a group basis (around two student mentors take care of a class of 40 students). The student mentors take part in this project through our established campus internship and other cocurricular experiential learning schemes.

In CoolThink@JC, a sustainable learning environment was created for a period of 3 years for the participating primary students to learn the skill to program and keep up the learning attitude. The main role of the CityU team is to provide in-class manpower support and parent involvement support, and to facilitate effective learning in target schools. CityU Apps Lab, an education community at CityU consisting of more than 600 University student members, is able to provide such manpower support throughout this project. It is expected that in 3 years' time, this community can grow up to 1,000 members on campus involving the CityU Alumni network. Students from other Hong Kong higher education institutions who are passionate about computational thinking (CT) and programming education are also recruited to join this project.

Yet, one challenge identified by the research group is the diverse cultures and backgrounds of the recruited students, which the cultural difference is expected to be overcome in the stress-adaption-growth (SOSAG) process in the recruitment.

In order to provide interactions with primary school students, we will provide support to the whole project to create a structured curriculum with the partnering organizations on this project that eventually integrates learning existing subjects such as mathematics and sciences with the computational thinking skills that the students have picked up. This has the potential to galvanize knowledge sharing and learning among the students. 


\subsection{Roles and Responsibilities of TAs}

In CoolThink@JC, 100 and 500 teaching assistants (TA) were recruited by CityU from over 10 tertiary institutions of Hong Kong in the academic years of 2016/17 and $2017 / 18$ to serve 32 pilot primary schools that participate in the computational thinking education in Hong Kong.

The main roles of TAs are to assist teachers in dealing with classroom teaching, e.g., co-teaching CT and answering students' enquiries in class in the pilot primary schools. They also help in creating a joyful and innovative learning environment, and act as a role model in the classroom (e.g., by providing a passionate and responsive presence).

Another major responsibility of TAs is to provide professional support to teachers in relation to teaching and learning. They have to motivate students' learning and encourage them to interact with others, for example, by praising students who have successfully completed the class exercises with creative ideas and are behaving well, and encouraging them to assist other classmates. Also, they take the role of inspiring students to generate creative ideas by encouraging students to finish their tasks by themselves with appropriate guidance. They have to be aware of student progress and achievements, and report any concerns regarding student matters to their supervisors, namely teaching leads (TLs).

\subsection{Service-Oriented Stress-Adaption-Growth (SOSAG) Process}

\subsubsection{Assessment and Stress}

TAs take the main role in providing support in CT lessons and act as an ultimate executor of co-teaching in primary schools. Before being assigned to serve in primary schools, potential candidates are trained and assessed based on their performances on a series of tests and teaching practices to become "qualified TAs".

Unlike other subjects or skill set training, teaching CT is not easy as learners are required to have thorough understanding of both concepts and mechanisms to acquire the thinking skills needed for asking questions, understanding problems, and identifying solutions. Training TAs to be qualified to provide support to CT teaching at a large scale is even more a challenging task. Instead of "spoon-feeding" candidates for the essential soft and hard skills as the knowledge for co-teaching CT, candidates are expected to have a good attitude and high motivation, especially in Stage 1 where there are frequent interactions between candidates and the assessor for examining candidates' understanding on CT concepts, CT practices, and CT perspectives. This ensures the training and assessment at a large scale can be conducted smoothly while maintaining quality. 
Among hundreds of TAs recruited from various academic background and experience, some do not have relevant education background while some lack relevant experiences, e.g., teaching or interacting with children. To overcome the cultural difference of a large group of TAs, assessments are crucial to evaluate and maintain the standard of TAs via various kinds of assessment methodologies. Potential candidates are exposed to stress in four stages of assessments, which include a test via electronic submission and interview screening (Stage 1), training assessment (Stage 2), teaching practice assessment (Stage 3), and probation assessment to be qualified TAs (Stage 4). The assessment stages are summarized in Fig. 18.1.

In various stages of assessments, stress is caused by the intercultural differences including but not limited to (i) education background (e.g., education, programming) and (ii) work experiences (e.g., teaching experience or experience with children). The potential challenges that new recruits for this program may face are highlighted and emphasized with an increasing extent in each stage to enlarge their stress, and therefore the adaption and growth eventually.

Many candidates expressed that they suffered from varying degree of anxiety, sorrow, and even pain in different stages due to the various reasons: some candidates are not confident to learn CT when being given a test related to Scratch in Stage 1; some are distressed when being asked to handle student issues during interview while some feel worried to handle a big class of students and answer all enquiries from students properly in the lesson.

To resolve the stress, adaptation takes place to promote qualitative transformation toward growth (Kim, 2001). We consider the "cultural shock" as a "catalyst" for potential TAs to adapt quickly and grow to make them fit in the roles in the service engagement.

\subsubsection{Adaptation}

Although stress may be considered as a negative emotion, an appropriate level of stress can be beneficial (Spencer-Oatey \& Franklin 2009). Studies show that people under higher frequency of stress have higher level of adaption (Kim, 2001). Adaptation to "intercultural" differences marks a change in terms of behavior and attitude. In the adaption process, we offer TAs debriefing and reflection in different assessment stages to allow for self-review and lesson observation for self-improvement; for example, some candidates showed stress when failing in teaching practice caused by lateness or unsatisfactory performance. They reflected on the importance of time management and preparation. 
Fig. 18.1 The stages of becoming a qualified TA in CoolThink@ JC of Hong Kong

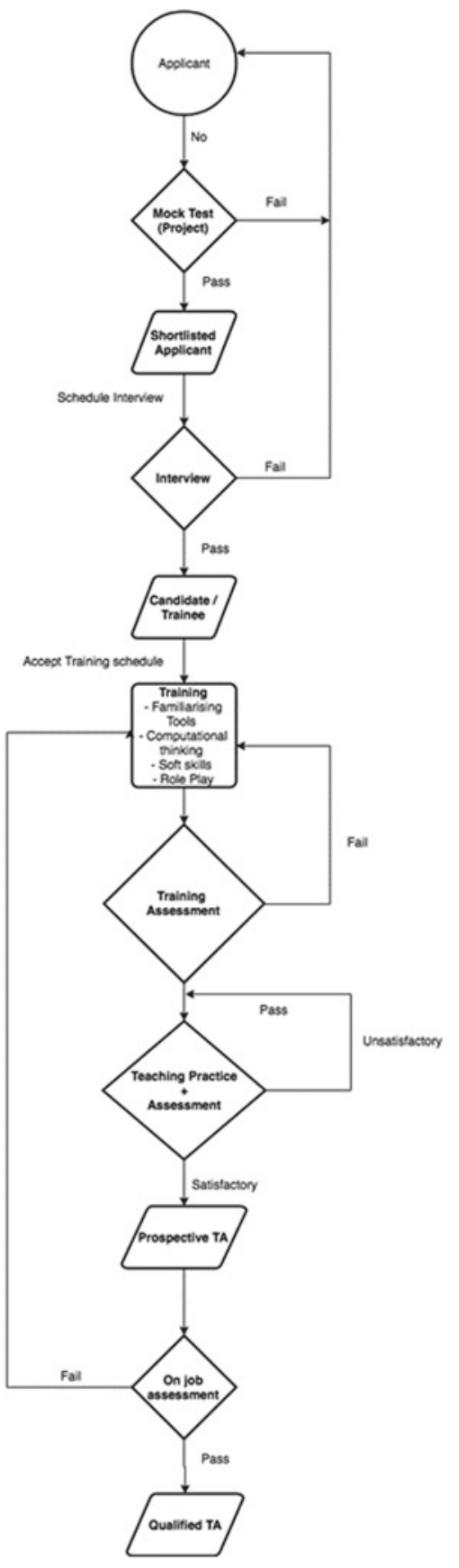


Table 18.1 ITT factors in the stages to become qualified TAs in CoolThink@ JC of Hong Kong

\begin{tabular}{|c|c|c|c|c|}
\hline \multirow[t]{2}{*}{ ITT factors } & \multicolumn{4}{|c|}{ SOSAG process } \\
\hline & $\begin{array}{l}\text { Stage } 1 \text {-Pre- } \\
\text { assessment }\end{array}$ & $\begin{array}{l}\text { Stage } \\
\text { 2-Training }\end{array}$ & $\begin{array}{l}\text { Stage } \\
\text { 3-Teaching } \\
\text { practice }\end{array}$ & $\begin{array}{l}\text { Stage } \\
4 \text {-Co-teaching (at } \\
\text { least } 2 \text { sessions) }\end{array}$ \\
\hline Stress & $\checkmark$ & $\checkmark$ & $\checkmark$ & $\checkmark$ \\
\hline Adaption & & $\checkmark$ & $\checkmark$ & $\checkmark$ \\
\hline Growth & & $\checkmark$ & $\checkmark$ & $\checkmark$ \\
\hline
\end{tabular}

\subsubsection{Growth}

Adaptation also leads to psychological growth and better understanding of who we are, what we value, and where we might want to go (Shi, 2006). The journey of becoming qualified TAs of CoolThink@JC in the form of service learning helps to achieve a balance between service outcomes and learning goals (Furco, 1996). Service and learning goals are of equal weight and each enhances the other for all participants in service-learning (Sigmon, 1994). In the case of TAs in this project, service refers to the co-teaching support provided to teachers and students at primary schools while learning refers to the growth of TAs.

During the service, TAs are required to identify a problem, propose a solution, and learn from the experience (Crutsinger, Pookulangara, Tran, \& Kim, 2004). During the lessons, TAs observe the students' learning progress to identify their problems, then think of a way to present the problem and to inspire the students to solve it. Experienced TAs usually learn from past experience to respond to students of different levels and characteristics for a better learning outcome.

We consider it a stress-adaption-growth process which eventually leads to the selfdevelopment of TAs. As an extension to the existing intercultural transformation theory (ITT), we propose that this multiple-stage service-oriented process leads to TAs' self-development as the "service-oriented stress-adaption-growth (SOSAG) process" highlights the growth via engaging candidates in service. The self-development of TAs is examined in Sect. 18.4-Evidences (Table 18.1).

\subsection{Evidence}

In this study, data was being collected and presented in the form of in-depth reflective summary submitted by TAs. The extracted content of the reflective summary was mapped against the corresponding factors of the stress-adaption-growth process of the intercultural transformation theory (ITT) (Kim \& Ruben, 1988). Five cases were examined in light of ITT factors through the different stages of the SOSAG process.

The TA subjects in this study were invited to reflect on a number of attributes (listed in Sect. 18.4.1-18.4.2) which are expected of a qualified TA in CoolThink@ JC. 


\subsubsection{Attitude}

- Understanding the importance of the sense of responsibility (e.g., punctuality, being well prepared).

- Stepping out the comfort zone to accept new challenges which may be out of their profession.

\subsubsection{Soft Skills}

\subsubsection{Communication Skills}

- Communicating with various stakeholders including supervisors, school teachers, students, and partner TAs (e.g., observing students' learning progress and problems, communicating with students to give them a helping hand, handling student behavioral and disciplinary issues occasionally, and resolve conflicts between students).

\subsubsection{Time and Stress Management}

- For example, handling a certain number of students inquiries and issues within the limited lesson time.

\subsubsection{Knowledge on CT and Programming}

- For example, using CT concerts to solve problems in daily life.

Table 18.2 summarizes the TAs' self-review comments through the SOSAG in the service engagement in CT education. The comments that correspond to the respective ITT factors are highlighted for further analysis.

\subsection{Discussion}

\subsubsection{Add-On Training}

For the enhancement of knowledge in computational thinking, supplementary training will be offered to the existing TAs. Based on train-the-trainer model, experienced TAs form a taskforce to be trainers to design and offer add-on training for junior TAs. 
Table 18.2 Excerpts from reflective summaries submitted by teaching assistants in CoolThink@ JC

\begin{tabular}{|c|c|}
\hline \multicolumn{2}{|c|}{ (a) Stage 1-Pre-assessment } \\
\hline $\begin{array}{l}\text { ITT } \\
\text { factors }\end{array}$ & Stage 1-Pre-assessment \\
\hline Stress & 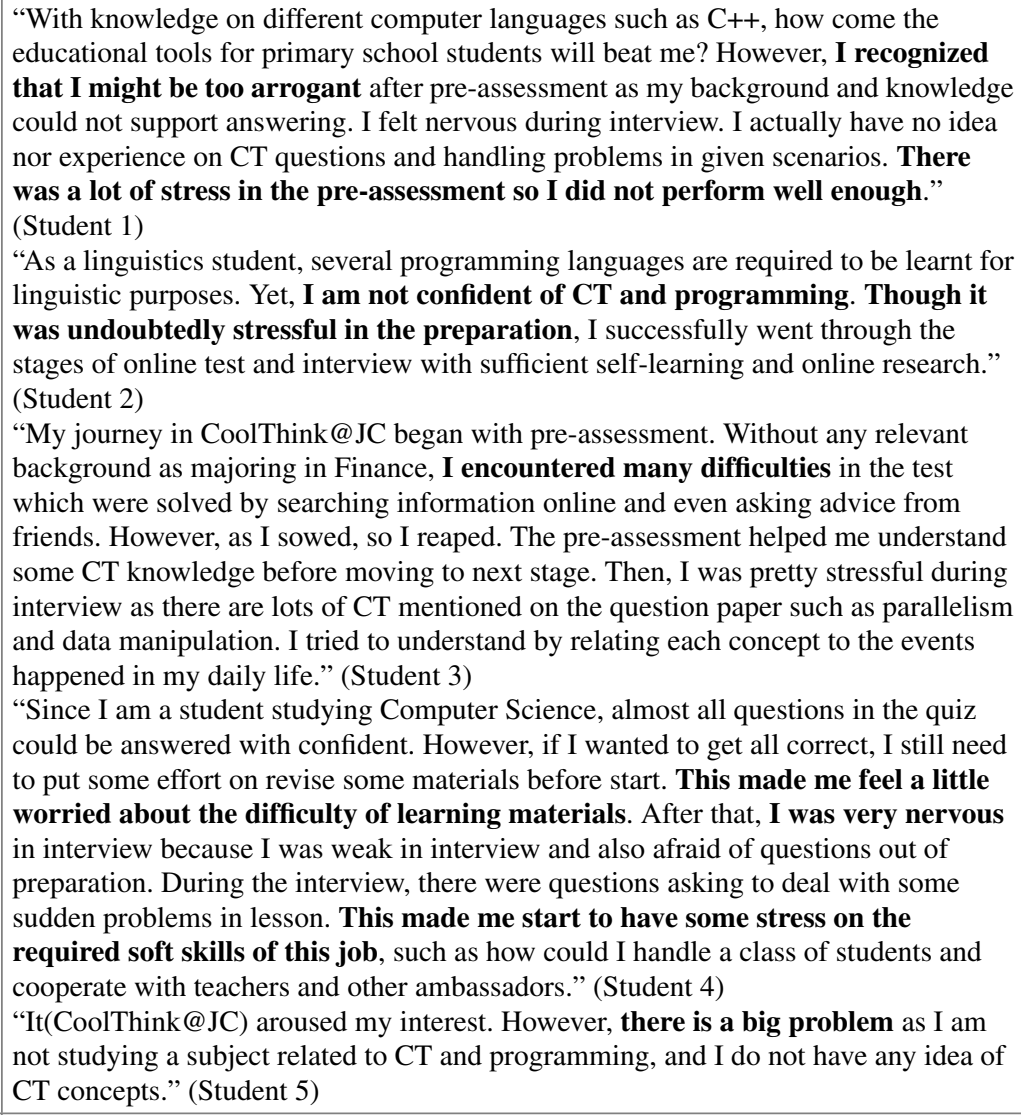 \\
\hline \multicolumn{2}{|c|}{ Adaption } \\
\hline Growth & \\
\hline
\end{tabular}


Table 18.2 (continued)

\begin{tabular}{|c|c|}
\hline $\begin{array}{l}\text { ITT } \\
\text { factors }\end{array}$ & Stage 2-Training \\
\hline Stress & $\begin{array}{l}\text { "I just remember that I was quite embarrassed to "perform" in front of the class. Even } \\
\text { worse, our demonstration was not comprehensive enough." (Student 1) } \\
\text { "Apart from the soft skill training, the hard skill coaching of Scratch and AI } 2 \text { in the } \\
\text { afternoon definitely enabled me to learn some solid skills. It was quite challenging } \\
\text { and stressful for me in the beginning. The learning process generally was } \\
\text { pleasurable thought I felt a bit left behind and stressful in digesting the excessive } \\
\text { new information in a limited time. Luckily, TLs and a friend of mine provided } \\
\text { guidance throughout the training." (Student } 2 \text { ) } \\
\text { "Sometimes I found I would lose myself in some steps and did not know where } \\
\text { can find some codes or forget what was the next step." (Student 4) }\end{array}$ \\
\hline Adaption & $\begin{array}{l}\text { "Luckily, CoolThink@ JC is a family; the professors gave us precious and useful } \\
\text { feedbacks and suggestions from their expert aspect, also other groups provided } \\
\text { supplementary methods from their experience. Besides, we enjoyed the excellent } \\
\text { performance of other groups and learnt to handle other situations." (Student 1) } \\
\text { "Coming up with an instruction sheet for other groups to fold a paper plane was also } \\
\text { fun-filled. It was a good chance for us to experience and recognize how to clearly } \\
\text { deliver a message to our audiences, allowing us to realize if our instructions are clear } \\
\text { and understandable for the receivers." (Student 2) } \\
\text { "I was no longer stressful about Scratch because previous knowledge learned from } \\
\text { pre-assessment allowed me to adapt new knowledge in CT faster." (Student } 3 \text { ) } \\
\text { "Even though everything seemed complicated to me, I received help from } \\
\text { supervisors. They were willing to help me when I had any problems encountered } \\
\text { during the training." (Student } 3 \text { ) } \\
\text { "Hence, I took myself as a student that I might help later on and remember what } \\
\text { problems I would face and observed how the teacher helped and solved those } \\
\text { problems." (Student } 4 \text { ) } \\
\text { "At the beginning, I just think that the CT concepts can only apply in programming } \\
\text { and computing. I never thought that CT concepts can exist in everywhere." (Student } \\
\text { 5) }\end{array}$ \\
\hline Growth & $\begin{array}{l}\text { "Hence, I realized self-study and practice are also important apart from training } \\
\text { provided." (Student 2) } \\
\text { "This improved my performance on how could I observe the students who might } \\
\text { want to ask some questions and assist them before they ask." (Student 4) }\end{array}$ \\
\hline
\end{tabular}


Table 18.2 (continued)

\begin{tabular}{|c|c|}
\hline \multicolumn{2}{|c|}{ (c) Stage 3-Teaching practice } \\
\hline $\begin{array}{l}\text { ITT } \\
\text { factors }\end{array}$ & Stage 3-Teaching practice \\
\hline Stress & $\begin{array}{l}\text { "Before I went to the teaching practice or co-teaching, I was a little bit worried. In } \\
\text { spite of the unknown situation that I might be faced in co-teaching, but I was also } \\
\text { worried that programming might be too difficult for the primary school students. } \\
\text { When I was in primary school, I just learned some background knowledge about the } \\
\text { computer hardware and history, plus some basic controls of computer only, instead of } \\
\text { coding or programing. Besides, I am afraid if CT or programming might be too } \\
\text { difficult for the immature kids to learn." (Student 1) } \\
\text { "Before getting involved in co-teaching, we were sent to gain practical experience via } \\
\text { teaching practice. I thought I was ready to overcome any difficulty. Nevertheless, } \\
\text { the thought was proven wrong. Since I was not aware about the school location and } \\
\text { arrival time, it took me long time to arrive. As result, I was late for my first ever } \\
\text { teaching practice. I felt guilty and ashamed about myself as I was not executing } \\
\text { my duty-Always on time. Also, I was stressful and worried about the impact." } \\
\text { (Student } 3 \text { ) } \\
\text { "However, I was a bit sad that my first teaching practice was failed due to } \\
\text { lateness. Although I was just late for a few minutes, I understood it should not } \\
\text { happen since every lesson at primary school is short and valuable. Being late is not } \\
\text { permitted and may affect the lesson quality like insufficient co-teaching support to } \\
\text { assist lesson delivery and cause extra troubles for the teachers like entering the room } \\
\text { suddenly and interrupting the lesson." (Student } 4 \text { ) } \\
\text { "In the second teaching practice, there were more TAs than usual situation in } \\
\text { co-teaching. With the help of the currently working ambassadors, the class could be } \\
\text { maintained in a good way. There were not many cases that some students were } \\
\text { lagging behind a lot. However, TAs and teacher were so busy with the teaching, } \\
\text { making me a bit worried of co-teaching and class management to solve students' } \\
\text { problem in the future." (Student } 4 \text { ) } \\
\text { "I still remember that I was very nervous when I had teaching practice in the } \\
\text { primary school because there were many things to pay attention, such as assisting } \\
\text { quality, classroom discipline and other uncertainties." (Student 5) }\end{array}$ \\
\hline Adaption & $\begin{array}{l}\text { "With preparations before the class, I could provide suggestions to help them." } \\
\text { (Student 1) } \\
\text { "Since it was my first teaching practice, the supervisor is willing to give me another } \\
\text { chance. When participating in another teaching practice, I understood that planning } \\
\text { should be always done before moving, which allows me to have sufficient time and } \\
\text { effort to complete the duty." (Student } 3 \text { ) } \\
\text { "I had more pressure in the second attempt and prepared more time than the last time } \\
\text { for taking transportation, finding ways and walking to prevent being late again, } \\
\text { therefore I arrived on time and could try to help the students with their needs." } \\
\text { (Student 4) } \\
\text { "Experience really helped a lot. The more problems we handled, the more we } \\
\text { experience we had to understand how to handle different cases. Therefore, I always } \\
\text { notice how other ambassadors and teacher supported different students, remind } \\
\text { myself how can I do in the similar condition." (Student } 4 \text { ) } \\
\text { "In the classroom, there were other experienced TAs. I took them as a reference and I } \\
\text { started to imitate the way they are." (Student 5) }\end{array}$ \\
\hline
\end{tabular}


Table 18.2 (continued)

\begin{tabular}{|c|c|}
\hline Growth & $\begin{array}{l}\text { "The teaching practice helped me a lot, as I gained the experience and knowledge to } \\
\text { control the whole class and teach the kids, also it strengthens my CT ability." } \\
\text { (Student 1) } \\
\text { "Through the teaching practice, I also noticed the duties of a teacher are not only } \\
\text { delivering the solid knowledge to students in the lesson, but also paying time and } \\
\text { effort to prepare teaching materials beforehand. It is very crucial to ignite students' } \\
\text { passion in the subject and hence motivate them to learn and further develop } \\
\text { their skills." (Student 2) } \\
\text { "I was satisfied to prove myself being able to handle the teaching practice." (Student } \\
\text { 3) } \\
\text { "I realized the importance of time management" (Student 4) } \\
\text { "Gradually, I build up my own set of practice. I am confident to have co-teaching and } \\
\text { I can be more mature to handle any difficulties." (Student 5) }\end{array}$ \\
\hline \multicolumn{2}{|c|}{ (d) Stage 4-Co-teaching } \\
\hline $\begin{array}{l}\text { ITT } \\
\text { factors }\end{array}$ & Stage 4-Co-teaching \\
\hline Stress & $\begin{array}{l}\text { "However, a certain level of stress came out as I was assigned to be the TA for } \\
\text { specific classes cooperating with the same teacher continuously. As I was no longer a } \\
\text { trainee conducting teaching practice in one random lesson, I had much more } \\
\text { responsibility to help the teacher while taking care the students as a regular TA of the } \\
\text { class." (Student 1) } \\
\text { "It is true that the students' characters from different schools are highly diverse, } \\
\text { regarding learning motivation, concentration as well as conduct in class. In some } \\
\text { schools, I always found the students are more creative and willing to learn. They } \\
\text { understand most of the content and able to work on their own with a little assistance. } \\
\text { In contrast, I feel stressed at some schools whose students show no interest in } \\
\text { Scratch and hence they are unwilling to listen and work on the assigned tasks. I } \\
\text { was frustrated and worried for students being reluctant to learn. It is } \\
\text { comparatively difficult to ignite their passion in Scratch." (Student } 2 \text { ) } \\
\text { "The most challenging part was going to different schools for co-teaching as the } \\
\text { variations include teachers, partner TAs, lesson venue, and teaching progress." } \\
\text { (Student } 4 \text { ) } \\
\text { "Here comes another challenge. Some students were very naught, who did not stay } \\
\text { at theit seat properly and kept talking with others. They acted obediently for a short } \\
\text { time after my warning and resume their naughty behavior again. I was a bit } \\
\text { confused as I did not know what I can do." }\end{array}$ \\
\hline
\end{tabular}


Table 18.2 (continued)

\begin{tabular}{|c|c|}
\hline Adaption & 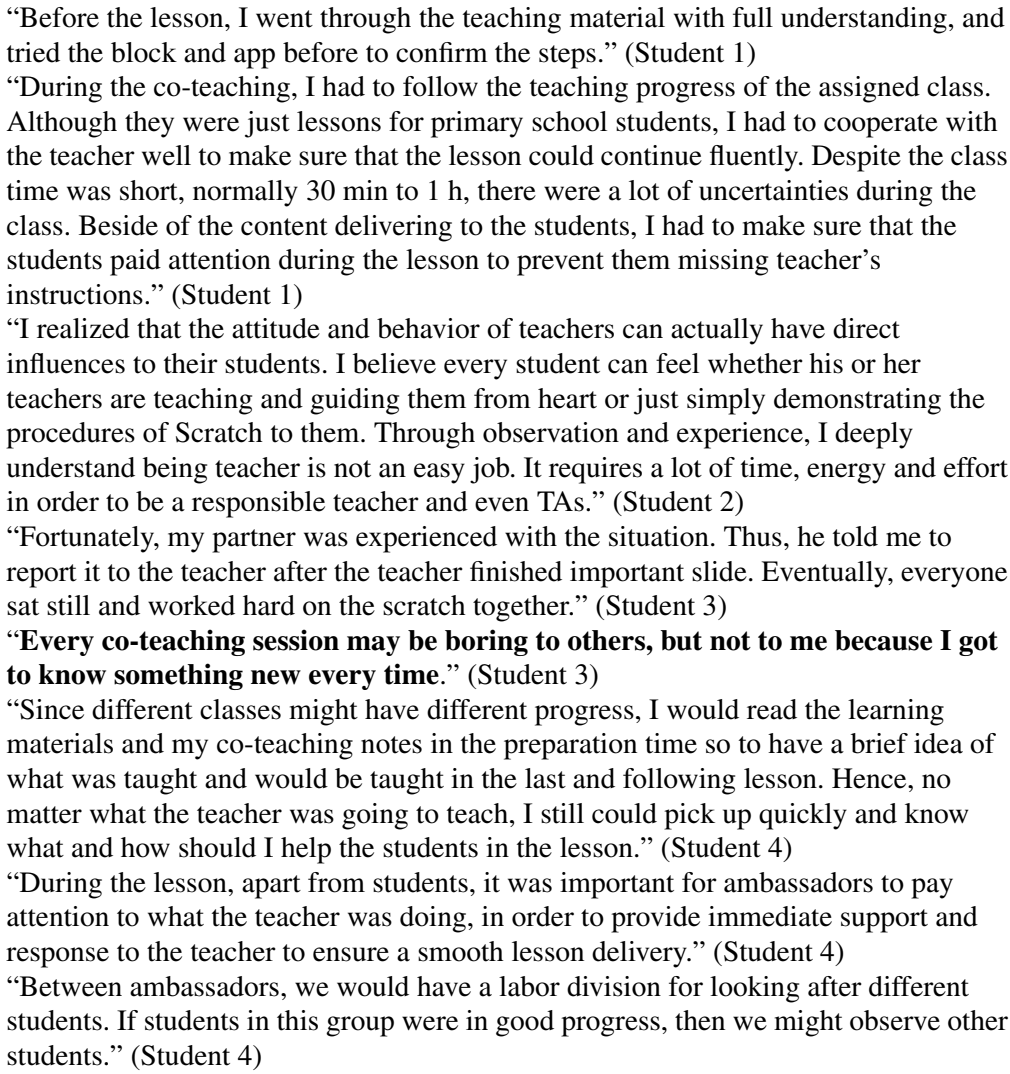 \\
\hline Growth & $\begin{array}{l}\text { "Not only do I step out my comfort zone to learn a discipline that I was not } \\
\text { familiar with, but I also get a taste of being a TA in primary school. Even though } \\
\text { being a teacher might not be the first priority in my future career path, various } \\
\text { training in this program enable me to understand the importance of the sense of } \\
\text { responsibility and having correct attitude at work. I have also realized nothing is } \\
\text { impossible if we are willing to learn from our mistakes and get along with stress, and } \\
\text { hopefully turn it into our motivation to become a better individual." (Student 2) } \\
\text { "For myself, I learned CT, which encouraged me to solve problem by searching } \\
\text { solution from different aspects. When solving problem, I would like to find out what } \\
\text { was the root to tackle the problem effectively and efficiently. Besides, it is important } \\
\text { to be responsible to perform or complete a task assigned satisfactorily and on time. I } \\
\text { am grateful to CoolThink@ JC which gives me chances to learn about the } \\
\text { computational thinking and correct personality that I need to have for my career. } \\
\text { Everyone I met here had always given me direction and feedback to push me } \\
\text { one step forward on my career path." (Student } 3 \text { ) } \\
\text { "Up till now, I have joined the CoolThink@ @C programme for more than a year. I } \\
\text { have participated in different posts such as co-teaching, backup duties and training } \\
\text { programme. Meanwhile, I am fortunate to become one of the supervisory TA. I } \\
\text { am delighted that I can involve in supervisor duties. Each post provides } \\
\text { different experiences for me. It makes me growth and it broadens my horizon. } \\
\text { In CoolThink @ JC, I do not only learn CT concept, but also equip myself with } \\
\text { different knowledge and skills." (Student 5) }\end{array}$ \\
\hline
\end{tabular}


Under sufficient guidance by supervisors, they can become a good trainer to incorporate interactivity and foster thought-provoking conversations among peers.

\subsubsection{Promotion}

Based on enhanced intercultural transformation theory (ITT) (Sivakumar \& Kwok, 2017), promotional exercises can be considered as "motivation" while add-on training and advice from supervisors are "support" in the TAs' SOSAG process.

After the completion of at least one semester of service, TAs are eligible to apply for promotion via self-application or supervisors' nomination. They may be promoted to "Senior TAs" or even "Supervisory TAs" based on the following factors:

- Personal motivation and willingness to take up additional duties.

- Experience.

- Performance review.

- Evaluation conducted during individual and group interview for promotion.

Promoted TAs are expected to take up additional duties including to act as the role model for TAs, to help new TAs get acquainted with work environment, and to assist supervisors in managing TAs by conducting a quality inspection in relation to co-teaching support in various schools irregularly.

Some senior and supervisory TAs also involve in designing and offering addon training to other TAs under the guidance of supervisors. They are trained to be the trainers. This train-the-trainer model allows outstanding TAs to maximize their potential ability.

\subsubsection{Challenges}

One of the biggest challenges in engaging hundreds of tertiary students in the CT education in primary schools is to maintain manpower bank. Due to the complexity of matching school lesson schedule and TA preferences according to availability and school location, a pool of well-trained TAs is needed to serve more than thirty primary schools. 

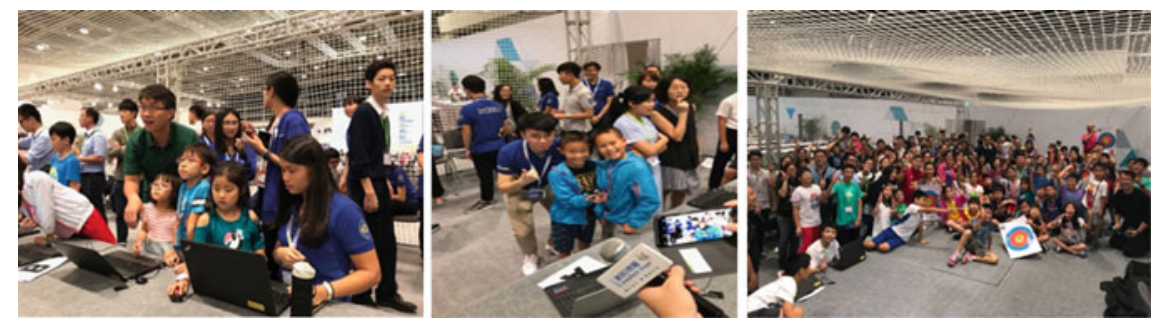

Fig. 18.2 TAs from CoolThink@ JC supported CT-related workshops in InnoTech 2017

If a similar model of providing co-teaching support were to be continually adopted in the $\mathrm{CT}$ education in primary schools, TA recruitment may need a wider and stronger support from all higher education institutions. Recognition of the importance of CT education and its impact by various parties in the society could be a significant motivator in the collaboration with higher education institutions. This mobilizes a bigger pool of potential TA candidates ready for screening process, and eventually allowing more suitable candidates can be identified. This is actually a win-win approach for both the service receivers (teachers and primary students) and givers (TAs).

\subsubsection{Future Directions}

Besides the duties of co-teaching in primary schools, TAs are also actively participating in the support of CT workshops for public, for example, some were sent to support programming workshops for the public in InnoTech Expo 2017, a large-scale innovation and technology event held in Hong Kong Convention and Exhibition Centre. Through co-organizing the events with volunteers from different backgrounds, TAs learned new knowledge like using programs to control drones and gained new exposure and insights to the application of programming in real life. The pictures in Fig. 18.2 show our TAs' engagement in the InnoTech Expo 2017.

In the long run, TAs with the experience in CT education will have a higher chance of engagement in CT education and related industries. Besides CT education, TAs are more likely to serve the community continually in different aspects and be more prepared to become future pillars in the society.

The potential development of qualified TAs is summarized and illustrated in Fig. 18.3. 


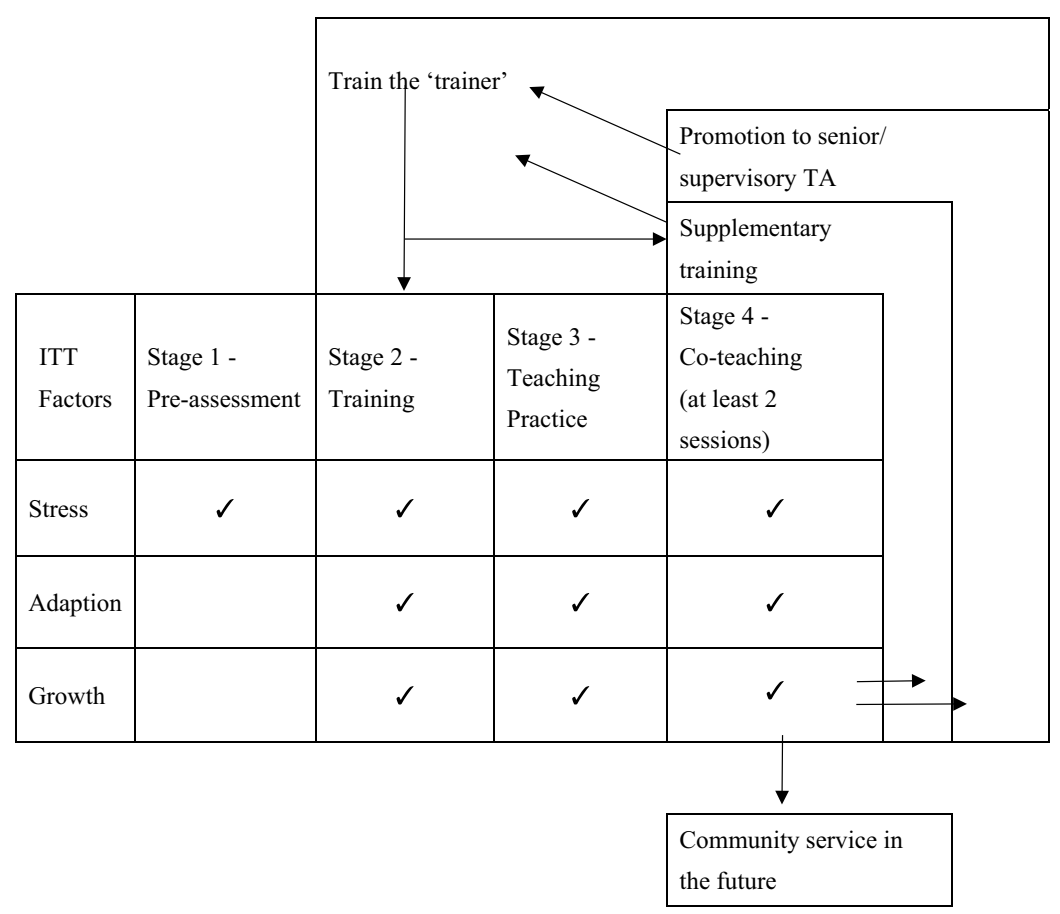

Fig. 18.3 Potential development of qualified TAs in CoolThink@ JC of Hong Kong

\subsection{Conclusion}

This chapter extends the existing intercultural transformation theory (ITT) and proposes the service-oriented stress-adaption-growth (SOSAG) process in the engagement of computational thinking co-teaching education. Through service engagement in CT education at primary schools, service-oriented stress-adaption-growth process took place and allowed TAs to undergo self-development in multiple stages. 


\section{Appendix}

\section{Case 1: Ordinary TAs}

\section{Student 1 from Electronic Engineering (Years of Service: 2016/17-2017/18)}

\begin{tabular}{|c|c|c|c|c|}
\hline $\begin{array}{l}\text { ITT } \\
\text { factors }\end{array}$ & $\begin{array}{l}\text { Stage } 1-\text { Pre- } \\
\text { assessment }\end{array}$ & Stage 2-Training & $\begin{array}{l}\text { Stage 3-Teaching } \\
\text { practice }\end{array}$ & Stage $4-$ Co-teaching \\
\hline Stress & $\begin{array}{l}\text { With knowledge } \\
\text { on different } \\
\text { computer } \\
\text { languages such } \\
\text { as C++, how } \\
\text { come the } \\
\text { educational } \\
\text { tools for } \\
\text { primary school } \\
\text { students will } \\
\text { beat me? } \\
\text { However, I } \\
\text { recognized that } \\
\text { I might be too } \\
\text { arrogant after } \\
\text { pre-assessment } \\
\text { as my } \\
\text { background and } \\
\text { knowledge } \\
\text { could not } \\
\text { support } \\
\text { answering. I felt } \\
\text { nervous during } \\
\text { interview. I } \\
\text { actually have no } \\
\text { idea nor } \\
\text { experience on } \\
\text { CT questions } \\
\text { and handling } \\
\text { problems in } \\
\text { given scenarios. } \\
\text { There was a lot } \\
\text { of stress in the } \\
\text { pre-assessment } \\
\text { so I did not } \\
\text { perform well } \\
\text { enough }\end{array}$ & $\begin{array}{l}\text { Some real situations that will } \\
\text { be faced in co-teaching were } \\
\text { given, such as how we can } \\
\text { handle and help the teacher } \\
\text { to control students during } \\
\text { the lesson. Each group was } \\
\text { required to demonstrate how } \\
\text { to solve potential problems } \\
\text { in front of other groups. Our } \\
\text { group topic was what should } \\
\text { ambassador do if students do } \\
\text { not follow the instructions of } \\
\text { the teacher and harass other } \\
\text { students. I did not remember } \\
\text { what we played in front of } \\
\text { the classroom; I just } \\
\text { remember that I was quite } \\
\text { embarrassed to "perform" in } \\
\text { front of the class. Even } \\
\text { worse, our demonstration } \\
\text { was not comprehensive } \\
\text { enough }\end{array}$ & $\begin{array}{l}\text { Before I went to the } \\
\text { teaching practice or } \\
\text { co-teaching, I was a little } \\
\text { bit worried. In spite of the } \\
\text { unknown situation that I } \\
\text { might be faced in } \\
\text { co-teaching, but I was also } \\
\text { worried that programming } \\
\text { might be too difficult for } \\
\text { the primary school } \\
\text { students. When I was in } \\
\text { primary school, I just } \\
\text { learned some background } \\
\text { knowledge about the } \\
\text { computer hardware and } \\
\text { history, plus some basic } \\
\text { controls of computer only, } \\
\text { instead of coding or } \\
\text { programing. Also, in my } \\
\text { generation, computer } \\
\text { science or programming } \\
\text { was not a core subject or } \\
\text { even not important. } \\
\text { Besides, I am afraid if CT } \\
\text { or programming might be } \\
\text { too difficult for the } \\
\text { immature kids to learn }\end{array}$ & $\begin{array}{l}\text { After the teaching practice, I } \\
\text { started my co-teaching } \\
\text { works. Similar with the } \\
\text { teaching practice, I found } \\
\text { my position to support the } \\
\text { teachers while answering } \\
\text { inquiries from students. } \\
\text { However, a certain level of } \\
\text { stress came out as I was } \\
\text { assigned to be the TA for } \\
\text { specific classes cooperating } \\
\text { with the same teacher } \\
\text { continuously. As I was no } \\
\text { longer a trainee conducting } \\
\text { teaching practice in one } \\
\text { random lesson, I had much } \\
\text { more responsibility to help } \\
\text { the teacher while taking care } \\
\text { the students as a regular TA } \\
\text { of the class }\end{array}$ \\
\hline
\end{tabular}




\begin{tabular}{|c|c|c|c|c|}
\hline $\begin{array}{l}\text { ITT } \\
\text { factors }\end{array}$ & $\begin{array}{l}\text { Stage } 1 \text {-Pre- } \\
\text { assessment }\end{array}$ & Stage 2-Training & $\begin{array}{l}\text { Stage } 3 \text {-Teaching } \\
\text { practice }\end{array}$ & Stage 4 -Co-teaching \\
\hline Adaption & & $\begin{array}{l}\text { Luckily, CoolThink@ JC is a } \\
\text { family; the professors gave } \\
\text { us precious and useful } \\
\text { feedbacks and suggestions } \\
\text { from their expert aspect, } \\
\text { also other groups provided } \\
\text { supplementary methods } \\
\text { from their experience. } \\
\text { Besides, we enjoyed the } \\
\text { excellent performance of } \\
\text { other groups and learnt to } \\
\text { handle other situations. } \\
\text { These role-play games gave } \\
\text { me a very good experience }\end{array}$ & 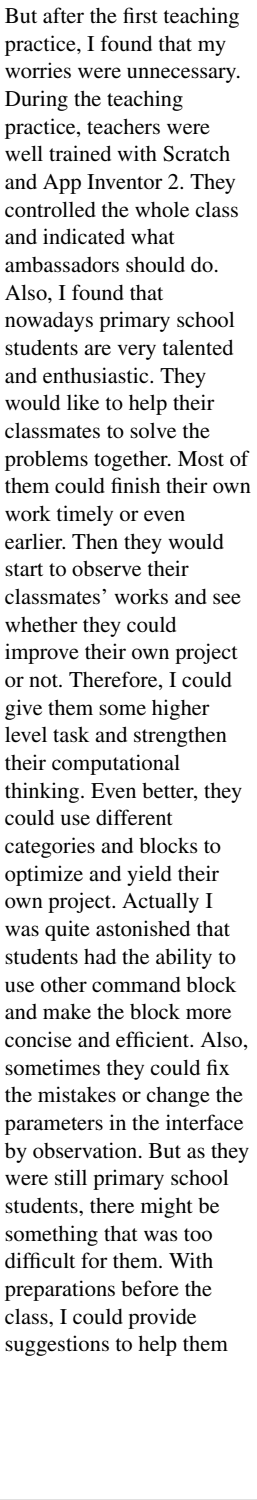 & 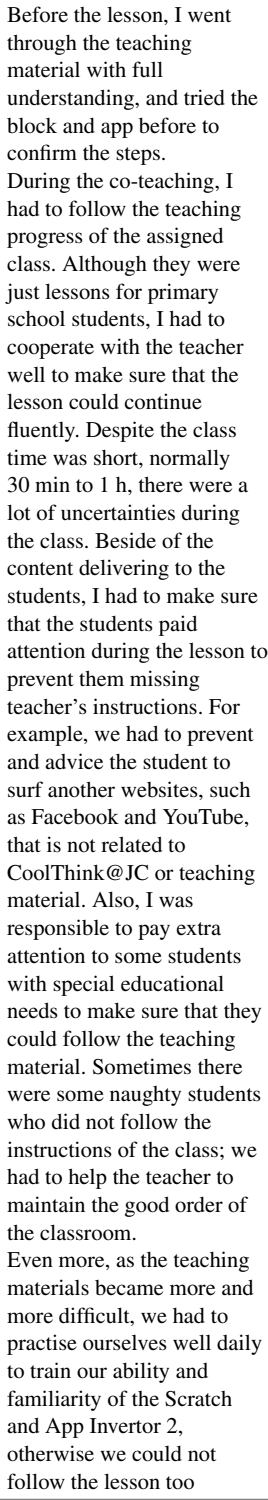 \\
\hline Growth & & $\begin{array}{l}\text { Not only does it help me to } \\
\text { solve common problems } \\
\text { we face in co-teaching, but } \\
\text { it also gains my experience } \\
\text { in co-teaching and makes } \\
\text { me calm down with no } \\
\text { disarray. These helped me a } \\
\text { lot }\end{array}$ & $\begin{array}{l}\text { The teaching practice } \\
\text { helped me a lot, as I gained } \\
\text { the experience and } \\
\text { knowledge to control the } \\
\text { whole class and teach the } \\
\text { kids, also it strengthens my } \\
\text { CT ability }\end{array}$ & $\begin{array}{l}\text { Until now, I am still just a } \\
\text { qualified TA but not a good } \\
\text { TA, as I believe a } \\
\text { well-prepared TA has to } \\
\text { practise and practise more } \\
\text { to gain the experience }\end{array}$ \\
\hline
\end{tabular}


Student 2 from Linguistics (Year of Service: 2017/18)

\begin{tabular}{|c|c|c|c|c|}
\hline $\begin{array}{l}\text { ITT } \\
\text { factors }\end{array}$ & Stage 1-Pre-assessment & Stage 2 -Training & $\begin{array}{l}\text { Stage 3-Teaching } \\
\text { practice }\end{array}$ & Stage 4-Co-teaching \\
\hline Stress & $\begin{array}{l}\text { As a linguistics student, } \\
\text { several programming } \\
\text { languages are required to } \\
\text { be learnt for linguistic } \\
\text { purposes. Yet, I am not } \\
\text { confident of CT and } \\
\text { programming. Though } \\
\text { it was undoubtedly } \\
\text { stressful in the } \\
\text { preparation, I } \\
\text { successfully went } \\
\text { through the stages of } \\
\text { online test and interview } \\
\text { with sufficient } \\
\text { self-learning and online } \\
\text { research }\end{array}$ & $\begin{array}{l}\text { A series of training and } \\
\text { briefing were arranged to } \\
\text { all of the ambassadors } \\
\text { after the selection. I } \\
\text { think the most } \\
\text { remarkable part would } \\
\text { be the 1-day training } \\
\text { workshop on both soft } \\
\text { and hard skills. With } \\
\text { role-playing training in } \\
\text { the morning, we are able } \\
\text { to understand how to } \\
\text { handle different } \\
\text { circumstances in } \\
\text { classroom, such as } \\
\text { resolving the quarrels } \\
\text { between students and } \\
\text { dealing with } \\
\text { emergencies in class. } \\
\text { Coming up with an } \\
\text { instruction sheet for } \\
\text { other groups to fold a } \\
\text { paper plane was also } \\
\text { fun-filled. It was a good } \\
\text { chance for us to } \\
\text { experience and } \\
\text { recognize how to clearly } \\
\text { deliver a message to our } \\
\text { audiences, allowing us to } \\
\text { realize if our instructions } \\
\text { are clear and } \\
\text { understandable for the } \\
\text { receivers. } \\
\text { Apart from the soft skill } \\
\text { training, the hard skill } \\
\text { coaching of Scratch and } \\
\text { AI2 in the afternoon } \\
\text { definitely enabled me to } \\
\text { learn some solid skills. It } \\
\text { was quite challenging } \\
\text { and stressful for me in } \\
\text { the beginning. The } \\
\text { learning process } \\
\text { generally was } \\
\text { pleasurable thought I } \\
\text { felt a bit left behind } \\
\text { and stressful in } \\
\text { digesting the excessive } \\
\text { new information in a } \\
\text { limited time. Luckily, } \\
\text { TLs and a friend of mine } \\
\text { provided guidance } \\
\text { throughout the training }\end{array}$ & Nil & $\begin{array}{l}\text { In the current time, I am } \\
\text { co-teaching at two primary } \\
\text { schools. It is true that the } \\
\text { students' characters from } \\
\text { different schools are highly } \\
\text { diverse, regarding learning } \\
\text { motivation, concentration } \\
\text { as well as conduct in class. } \\
\text { In some schools, I always } \\
\text { found the students are } \\
\text { more creative and willing } \\
\text { to learn. They understand } \\
\text { most of the content and } \\
\text { able to work on their own } \\
\text { with a little assistance. In } \\
\text { contrast, I feel stressed at } \\
\text { some schools whose } \\
\text { students show no interest } \\
\text { in Scratch and hence they } \\
\text { are unwilling to listen } \\
\text { and work on the assigned } \\
\text { tasks. I also observed that } \\
\text { most of them rather } \\
\text { chitchat with their } \\
\text { classmates instead of } \\
\text { listening to the teacher. I } \\
\text { usually have to guide them } \\
\text { from the very first step } \\
\text { until the last step, given } \\
\text { that they are willing and } \\
\text { patient to listen. I was } \\
\text { frustrated and worried } \\
\text { for students being } \\
\text { reluctant to learn. It is } \\
\text { comparatively difficult to } \\
\text { ignite their passion in } \\
\text { Scratch }\end{array}$ \\
\hline
\end{tabular}




\begin{tabular}{|c|c|c|c|c|}
\hline $\begin{array}{l}\text { ITT } \\
\text { factors }\end{array}$ & Stage 1-Pre-assessment & Stage 2-Training & $\begin{array}{l}\text { Stage 3-Teaching } \\
\text { practice }\end{array}$ & Stage $4-$ Co-teaching \\
\hline Adaption & & $\begin{array}{l}\text { Hence, I realized } \\
\text { self-study and practice } \\
\text { are also important apart } \\
\text { from training provided }\end{array}$ & $\begin{array}{l}\text { During teaching } \\
\text { practice, hands-on } \\
\text { experience was the } \\
\text { most valuable reward } \\
\text { for me. It was my } \\
\text { first time being a TA } \\
\text { in school and I was } \\
\text { glad that the whole } \\
\text { teaching process was } \\
\text { smooth and } \\
\text { manageable }\end{array}$ & $\begin{array}{l}\text { Furthermore, the teaching } \\
\text { styles are very distinct in } \\
\text { different schools. Through } \\
\text { multiple duties in various } \\
\text { schools, I have learned that } \\
\text { I should always try my best } \\
\text { to assist the students to } \\
\text { catch up with their teacher. } \\
\text { I realized that the attitude } \\
\text { and behavior of teachers } \\
\text { can actually have direct } \\
\text { influences to their students. } \\
\text { I believe every student can } \\
\text { feel whether his or her } \\
\text { teachers are teaching and } \\
\text { guiding them from heart or } \\
\text { just simply demonstrating } \\
\text { the procedures of Scratch } \\
\text { to them. Through } \\
\text { observation and } \\
\text { experience, I deeply } \\
\text { understand being teacher is } \\
\text { not an easy job. It requires } \\
\text { a lot of time, energy and } \\
\text { effort in order to be a } \\
\text { responsible teacher and } \\
\text { even TAs }\end{array}$ \\
\hline Growth & & $\begin{array}{l}\text { Generally, we all think } \\
\text { we have stepped out } \\
\text { our comfort zone and } \\
\text { accepted new } \\
\text { challenges beyond our } \\
\text { school professions }\end{array}$ & $\begin{array}{l}\text { Through the teaching } \\
\text { practice, I also } \\
\text { noticed the duties of } \\
\text { a teacher are not only } \\
\text { delivering the solid } \\
\text { knowledge to } \\
\text { students in the lesson, } \\
\text { but also paying time } \\
\text { and effort to prepare } \\
\text { teaching materials } \\
\text { beforehand. It is very } \\
\text { crucial to ignite } \\
\text { students' passion in } \\
\text { the subject and } \\
\text { hence motivate them } \\
\text { to learn and further } \\
\text { develop their skills }\end{array}$ & $\begin{array}{l}\text { To conclude, it is true to } \\
\text { say that I have learned so } \\
\text { much since the first day of } \\
\text { this program. After going } \\
\text { through different stages, I } \\
\text { have become a qualified } \\
\text { Teaching Assistant in } \\
\text { CoolThink @ JC. It has } \\
\text { certainly been a precious } \\
\text { experience in my } \\
\text { University life. Not only } \\
\text { do I step out my comfort } \\
\text { zone to learn a discipline } \\
\text { that I was not familiar } \\
\text { with, but I also get a taste } \\
\text { of being a TA in primary } \\
\text { school. Even though being } \\
\text { a teacher might not be the } \\
\text { first priority in my future } \\
\text { career path, various } \\
\text { training in this program } \\
\text { enable me to understand } \\
\text { the importance of the sense } \\
\text { of responsibility and } \\
\text { having correct attitude at } \\
\text { work. I have also realized } \\
\text { nothing is impossible if we } \\
\text { are willing to learn from } \\
\text { our mistakes and get along } \\
\text { with stress, and hopefully } \\
\text { turn it into our motivation } \\
\text { to become a better } \\
\text { individual }\end{array}$ \\
\hline
\end{tabular}




\section{Case 2: TAs who are required to redo Teaching Practice}

Student 3 from business (Year of Service: 2017/18)

\begin{tabular}{|c|c|c|c|c|}
\hline $\begin{array}{l}\text { ITT } \\
\text { factors }\end{array}$ & $\begin{array}{l}\text { Stage } \\
1 \text {-Pre-assessment }\end{array}$ & Stage 2-Training & $\begin{array}{l}\text { Stage } \\
3 \text {-Teaching } \\
\text { practice }\end{array}$ & $\begin{array}{l}\text { Stage } \\
4-\text { Co-teaching }\end{array}$ \\
\hline Stress & $\begin{array}{l}\text { My journey in } \\
\text { CoolThink@ JC } \\
\text { began with } \\
\text { pre-assessment. } \\
\text { Without any } \\
\text { relevant } \\
\text { background as } \\
\text { majoring in } \\
\text { Finance, I } \\
\text { encountered many } \\
\text { difficulties in the } \\
\text { test which were } \\
\text { solved by searching } \\
\text { information online } \\
\text { and even asking } \\
\text { advice from } \\
\text { friends. However, } \\
\text { as I sowed, so I } \\
\text { reaped. The } \\
\text { pre-assessment } \\
\text { helped me } \\
\text { understand some } \\
\text { CT knowledge } \\
\text { before moving to } \\
\text { next stage. Then, I } \\
\text { was pretty stressful } \\
\text { during interview as } \\
\text { there are lots of CT } \\
\text { mentioned on the } \\
\text { question paper } \\
\text { such as parallelism } \\
\text { and data } \\
\text { manipulation. I } \\
\text { tried to understand } \\
\text { by relating each } \\
\text { concept to the } \\
\text { events happened in } \\
\text { my daily life }\end{array}$ & $\begin{array}{l}\text { After successfully } \\
\text { entered group of } \\
\text { TAs in } \\
\text { CoolThink@ JC, I } \\
\text { must complete the } \\
\text { training before I } \\
\text { start my duty. In } \\
\text { training, I learned } \\
\text { more about } \\
\text { computational } \\
\text { thinking and } \\
\text { making my own } \\
\text { application such as } \\
\text { piano application }\end{array}$ & $\begin{array}{l}\text { Before getting } \\
\text { involved in } \\
\text { co-teaching, we } \\
\text { were sent to } \\
\text { gain practical } \\
\text { experience via } \\
\text { teaching } \\
\text { practice. I } \\
\text { thought I was } \\
\text { ready to } \\
\text { overcome any } \\
\text { difficulty. } \\
\text { Nevertheless, } \\
\text { the thought } \\
\text { was proven } \\
\text { wrong. Since I } \\
\text { was not aware } \\
\text { about the school } \\
\text { location and } \\
\text { arrival time, it } \\
\text { took me long } \\
\text { time to arrive. } \\
\text { As result, I was } \\
\text { late for my first } \\
\text { ever teaching } \\
\text { practice. I felt } \\
\text { guilty and } \\
\text { ashamed about } \\
\text { myself as I was } \\
\text { not executing } \\
\text { my } \\
\text { duty-Always } \\
\text { on time. Also, I } \\
\text { was stressful } \\
\text { and worried } \\
\text { about the } \\
\text { impact }\end{array}$ & $\begin{array}{l}\text { Finally, getting into } \\
\text { co-teaching session, } \\
\text { as I have planned the } \\
\text { route to the primary } \\
\text { school before hand, } \\
\text { I got to there on } \\
\text { time. Here comes } \\
\text { another challenge. } \\
\text { Some students were } \\
\text { very naught, who } \\
\text { did not stay at their } \\
\text { seat properly and } \\
\text { kept talking with } \\
\text { others. They acted } \\
\text { obediently for a } \\
\text { short time after my } \\
\text { warning and resume } \\
\text { their naughty } \\
\text { behavior again. I } \\
\text { was a bit confused } \\
\text { as I did not know } \\
\text { what I can do }\end{array}$ \\
\hline
\end{tabular}


(continued)

\begin{tabular}{|c|c|c|c|c|}
\hline $\begin{array}{l}\text { ITT } \\
\text { factors }\end{array}$ & $\begin{array}{l}\text { Stage } \\
1 \text {-Pre-assessment }\end{array}$ & Stage 2-Training & $\begin{array}{l}\text { Stage } \\
\text { 3-Teaching } \\
\text { practice }\end{array}$ & $\begin{array}{l}\text { Stage } \\
\text { 4-Co-teaching }\end{array}$ \\
\hline Adaption & & $\begin{array}{l}\text { I was no longer } \\
\text { stressful about } \\
\text { handling the } \\
\text { Scratch because } \\
\text { previous } \\
\text { knowledge learned } \\
\text { from } \\
\text { pre-assessment } \\
\text { allowed me to } \\
\text { adapt new } \\
\text { knowledge in CT } \\
\text { faster. Besides, I } \\
\text { learned about how } \\
\text { to execute } \\
\text { co-teaching } \\
\text { practice in next } \\
\text { academic year. } \\
\text { What I should do } \\
\text { and what should be } \\
\text { avoided during } \\
\text { co-teaching duty. } \\
\text { Even though } \\
\text { everything seemed } \\
\text { complicated to me, } \\
\text { I received help } \\
\text { from supervisors. } \\
\text { They were willing } \\
\text { to help me when I } \\
\text { had any problems } \\
\text { encountered during } \\
\text { the training }\end{array}$ & $\begin{array}{l}\text { Since it was my } \\
\text { first teaching } \\
\text { practice, the } \\
\text { supervisor is } \\
\text { willing to give } \\
\text { me another } \\
\text { chance. When } \\
\text { participating in } \\
\text { another teaching } \\
\text { practice, I } \\
\text { understood that } \\
\text { planning should } \\
\text { be always done } \\
\text { before moving, } \\
\text { which allows } \\
\text { me to have } \\
\text { sufficient time } \\
\text { and effort to } \\
\text { complete the } \\
\text { duty. Eventually, } \\
\text { I came earlier } \\
\text { because I did } \\
\text { preparation } \\
\text { before the } \\
\text { practice }\end{array}$ & $\begin{array}{l}\text { Fortunately, my } \\
\text { partner was } \\
\text { experienced with the } \\
\text { situation. Thus, he } \\
\text { told me to report it } \\
\text { to the teacher after } \\
\text { the teacher finished } \\
\text { important slide. } \\
\text { Eventually, everyone } \\
\text { sat still and worked } \\
\text { hard on the scratch } \\
\text { together. } \\
\text { Every co-teaching } \\
\text { session may be } \\
\text { boring to others, } \\
\text { but not to me } \\
\text { because I got to } \\
\text { know something } \\
\text { new every time. The } \\
\text { method of creating } \\
\text { an application was } \\
\text { revised for me every } \\
\text { time when I have } \\
\text { co-teaching session. } \\
\text { Besides, students' } \\
\text { creativity can always } \\
\text { surprise me. For } \\
\text { example, in doing } \\
\text { the maze run on } \\
\text { scratch, some } \\
\text { students made it as } \\
\text { Halloween version, } \\
\text { while some added } \\
\text { elements that were } \\
\text { not mentioned. I } \\
\text { believe in the future, } \\
\text { some of them can } \\
\text { become great } \\
\text { programmer with } \\
\text { lots of creativity and } \\
\text { create more useful } \\
\text { applications for us }\end{array}$ \\
\hline
\end{tabular}


(continued)

\begin{tabular}{|c|c|c|c|c|}
\hline $\begin{array}{l}\text { ITT } \\
\text { factors }\end{array}$ & $\begin{array}{l}\text { Stage } \\
1 \text {-Pre-assessment }\end{array}$ & Stage 2-Training & $\begin{array}{l}\text { Stage } \\
\text { 3-Teaching } \\
\text { practice }\end{array}$ & $\begin{array}{l}\text { Stage } \\
4 \text {-Co-teaching }\end{array}$ \\
\hline Growth & & Nil & $\begin{array}{l}\text { I was satisfied to } \\
\text { prove myself } \\
\text { being able to } \\
\text { handle the } \\
\text { teaching } \\
\text { practice }\end{array}$ & $\begin{array}{l}\text { For myself, I learned } \\
\text { CT, which } \\
\text { encouraged me to } \\
\text { solve problem by } \\
\text { searching solution } \\
\text { from different } \\
\text { aspects. When } \\
\text { solving problem, I } \\
\text { would like to find } \\
\text { out what was the } \\
\text { root to tackle the } \\
\text { problem effectively } \\
\text { and efficiently. } \\
\text { Besides, it is } \\
\text { important to be } \\
\text { responsible to } \\
\text { perform or complete } \\
\text { a task assigned } \\
\text { satisfactorily and on } \\
\text { time. If I don't } \\
\text { perform the task } \\
\text { satisfactorily and on } \\
\text { time, students and } \\
\text { teacher may suffer } \\
\text { as teacher cannot } \\
\text { handle all the } \\
\text { students at once and } \\
\text { chaos may occur. I } \\
\text { am grateful to } \\
\text { CoolThink } \text { JC } \\
\text { which gives me } \\
\text { chances to learn } \\
\text { about the } \\
\text { computational } \\
\text { thinking and correct } \\
\text { personality that I } \\
\text { need to have for my } \\
\text { career. Everyone I } \\
\text { met here had } \\
\text { always given me } \\
\text { direction and } \\
\text { feedback to push } \\
\text { me one step } \\
\text { forward on my } \\
\text { career path }\end{array}$ \\
\hline
\end{tabular}


Student 4 from Computer Science (Year of Service: 2017/18)

\begin{tabular}{|c|c|c|c|c|}
\hline $\begin{array}{l}\text { ITT } \\
\text { factors }\end{array}$ & $\begin{array}{l}\text { Stage } \\
1 \text {-Pre-assessment }\end{array}$ & Stage 2-Training & $\begin{array}{l}\text { Stage } 3 \text {-Teaching } \\
\text { practice }\end{array}$ & Stage $4-$ Co-teaching \\
\hline Stress & $\begin{array}{l}\text { Since I am a student } \\
\text { studying Computer } \\
\text { Science, almost all } \\
\text { questions in the quiz } \\
\text { could be answered } \\
\text { with confident. } \\
\text { However, if I wanted } \\
\text { to get all correct, I still } \\
\text { need to put some effort } \\
\text { on revise some } \\
\text { materials before start. } \\
\text { This made me feel a } \\
\text { little worried about } \\
\text { the difficulty of } \\
\text { learning materials. } \\
\text { After that, I was very } \\
\text { nervous in interview } \\
\text { because I was weak in } \\
\text { interview and also } \\
\text { afraid of questions out } \\
\text { of preparation. During } \\
\text { the interview, there } \\
\text { were questions asking } \\
\text { to deal with some } \\
\text { sudden problems in } \\
\text { lesson. This made me } \\
\text { start to have some } \\
\text { stress on the required } \\
\text { soft skills of this job, } \\
\text { such as how could I } \\
\text { handle a class of } \\
\text { students and cooperate } \\
\text { with teachers and } \\
\text { other ambassadors }\end{array}$ & $\begin{array}{l}\text { After being shortlisted } \\
\text { as an ambassador, a } \\
\text { 1-day training was } \\
\text { conducted to reinforce } \\
\text { the knowledge of the } \\
\text { programming tools } \\
\text { which are the learning } \\
\text { materials for students. } \\
\text { Sometimes I found I } \\
\text { would lose myself in } \\
\text { some steps and did } \\
\text { not know where can } \\
\text { find some codes or } \\
\text { forget what was the } \\
\text { next step }\end{array}$ & $\begin{array}{l}\text { Before I go co-teaching in } \\
\text { the schools, a teaching } \\
\text { practice was needed for } \\
\text { giving me a preview of } \\
\text { what co-teaching is doing } \\
\text { in real situation. I think I } \\
\text { can learn some soft skills } \\
\text { like how to work with } \\
\text { other ambassadors and } \\
\text { teachers so to make me } \\
\text { more confident to do this } \\
\text { job. However, I was a bit } \\
\text { sad that my first teaching } \\
\text { practice was failed due to } \\
\text { lateness. Although I was } \\
\text { just late for a few minutes, } \\
\text { I understood it should not } \\
\text { happen since every lesson } \\
\text { at primary school is short } \\
\text { and valuable. Being late is } \\
\text { not permitted and may } \\
\text { affect the lesson quality } \\
\text { like insufficient } \\
\text { co-teaching support to } \\
\text { assist lesson delivery and } \\
\text { cause extra troubles for the } \\
\text { teachers like entering the } \\
\text { room suddenly and } \\
\text { interrupting the lesson. } \\
\text { In the second teaching } \\
\text { practice, there were more } \\
\text { TAs than usual situation in } \\
\text { co-teaching. With the help } \\
\text { of the currently working } \\
\text { ambassadors, the class } \\
\text { could be maintained in a } \\
\text { good way. There were not } \\
\text { many cases that some } \\
\text { students were lagging } \\
\text { behind a lot. However, TAs } \\
\text { and teacher were so busy } \\
\text { with the teaching, making } \\
\text { me a bit worried of } \\
\text { co-teaching and class } \\
\text { management to solve } \\
\text { students' problem in the } \\
\text { future }\end{array}$ & $\begin{array}{l}\text { The most challenging part } \\
\text { was going to different } \\
\text { schools for co-teaching as } \\
\text { the variations include } \\
\text { teachers, partner TAs, } \\
\text { lesson venue, and teaching } \\
\text { progress }\end{array}$ \\
\hline
\end{tabular}




\begin{tabular}{|c|c|c|c|c|}
\hline $\begin{array}{l}\text { ITT } \\
\text { factors }\end{array}$ & $\begin{array}{l}\text { Stage } \\
1 \text {-Pre-assessment }\end{array}$ & Stage 2-Training & $\begin{array}{l}\text { Stage } 3 \text {-Teaching } \\
\text { practice }\end{array}$ & Stage $4-$ Co-teaching \\
\hline Adaption & & $\begin{array}{l}\text { Hence, I took myself } \\
\text { as a student that I } \\
\text { might help later on } \\
\text { and remember what } \\
\text { problems I would face } \\
\text { and observed how the } \\
\text { teacher helped and } \\
\text { solved those problems }\end{array}$ & $\begin{array}{l}\text { I had more pressure in the } \\
\text { second attempt and } \\
\text { prepared more time than } \\
\text { the last time for taking } \\
\text { transportation, finding } \\
\text { ways and walking to } \\
\text { prevent being late again, } \\
\text { therefore I arrived on time } \\
\text { and could try to help the } \\
\text { students with their needs. } \\
\text { Experience really helped a } \\
\text { lot. The more problems we } \\
\text { handled, the more we } \\
\text { experience we had to } \\
\text { understand how to handle } \\
\text { different cases. Therefore, } \\
\text { I always notice how other } \\
\text { ambassadors and teacher } \\
\text { supported different } \\
\text { students, remind myself } \\
\text { how can I do in the similar } \\
\text { condition }\end{array}$ & $\begin{array}{l}\text { Before the lesson, there } \\
\text { was some time for } \\
\text { ambassadors to prepare. } \\
\text { Since different classes } \\
\text { might have different } \\
\text { progress, I would read the } \\
\text { learning materials and my } \\
\text { co-teaching notes in the } \\
\text { preparation time so to have } \\
\text { a brief idea of what was } \\
\text { taught and would be taught } \\
\text { in the last and following } \\
\text { lesson. Hence, no matter } \\
\text { what the teacher was going } \\
\text { to teach, I still could pick } \\
\text { up quickly and know what } \\
\text { and how should I help the } \\
\text { students in the lesson. } \\
\text { During the lesson, apart } \\
\text { from students, it was } \\
\text { important for ambassadors } \\
\text { to pay attention to what the } \\
\text { teacher was doing, in order } \\
\text { to provide immediate } \\
\text { support and response to the } \\
\text { teacher to ensure a smooth } \\
\text { lesson delivery. For } \\
\text { example, when the teacher } \\
\text { was mentioning some } \\
\text { worksheets and we might } \\
\text { help teacher to distribute } \\
\text { the materials so to save } \\
\text { time or when the teacher } \\
\text { asked the students to } \\
\text { follow to do the tasks, then } \\
\text { we might start checking } \\
\text { the progress of the students } \\
\text { and provide help when } \\
\text { necessary. } \\
\text { Between ambassadors, we } \\
\text { would have a labor division } \\
\text { for looking after different } \\
\text { students. If students in this } \\
\text { group were in good } \\
\text { progress, then we might } \\
\text { observe other students }\end{array}$ \\
\hline Growth & & $\begin{array}{l}\text { This improved my } \\
\text { performance on how } \\
\text { could I observe the } \\
\text { students who might } \\
\text { want to ask some } \\
\text { questions and assist } \\
\text { them before they ask }\end{array}$ & $\begin{array}{l}\text { I realized the importance } \\
\text { of time management }\end{array}$ & Nil \\
\hline
\end{tabular}


Case 3: Outstanding TAs

Student 5 from Public Policy (Years of Service: 2016/17-2017/18) who was promoted to supervisory TA after a year of service

\begin{tabular}{|c|c|c|c|c|}
\hline $\begin{array}{l}\text { ITT } \\
\text { factors }\end{array}$ & $\begin{array}{l}\text { Stage 1-Pre- } \\
\text { assessment }\end{array}$ & Stage 2 -Training & $\begin{array}{l}\text { Stage } \\
3 \text {-Teaching } \\
\text { practice }\end{array}$ & $\begin{array}{l}\text { Stage } \\
4-\text { Co-teaching }\end{array}$ \\
\hline Stress & $\begin{array}{l}\text { CoolThink@ JC } \\
\text { invited } \\
\text { university's } \\
\text { student to be a } \\
\text { teaching } \\
\text { assistant. It } \\
\text { aroused my } \\
\text { interest. } \\
\text { However, there } \\
\text { is a big } \\
\text { problem as I am } \\
\text { not studying a } \\
\text { subject related } \\
\text { to CT and } \\
\text { programming, } \\
\text { and I do not } \\
\text { have any idea of } \\
\text { CT concepts. } \\
\text { On the other } \\
\text { hand, I realized } \\
\text { that it is a rare } \\
\text { chance for me to } \\
\text { be a teaching } \\
\text { assistant. In } \\
\text { view of this, I } \\
\text { apply to the } \\
\text { application. To } \\
\text { be honest, it is } \\
\text { quite frustrating. } \\
\text { It is because } \\
\text { there were a } \\
\text { quiz and an } \\
\text { interview which } \\
\text { determine } \\
\text { whether I can be } \\
\text { a TA. Without } \\
\text { any related } \\
\text { knowledge, I } \\
\text { may not have a } \\
\text { good } \\
\text { performance }\end{array}$ & $\begin{array}{l}\text { At the beginning, I } \\
\text { just think that the CT } \\
\text { concepts can only } \\
\text { apply in programming } \\
\text { and computing. I } \\
\text { never thought that CT } \\
\text { concepts can exist in } \\
\text { everywhere }\end{array}$ & $\begin{array}{l}\text { Before having } \\
\text { constant } \\
\text { co-teaching, all } \\
\text { the TAs must } \\
\text { attend teaching } \\
\text { practice that TL } \\
\text { will assess the } \\
\text { performance of } \\
\text { TAs. I still } \\
\text { remember that I } \\
\text { was very } \\
\text { nervous when I } \\
\text { had teaching } \\
\text { practice in the } \\
\text { primary school } \\
\text { because there } \\
\text { were many } \\
\text { things to pay } \\
\text { attention, such } \\
\text { as assisting } \\
\text { quality, } \\
\text { classroom } \\
\text { discipline and } \\
\text { other } \\
\text { uncertainties }\end{array}$ & Nil \\
\hline
\end{tabular}


(continued)

\begin{tabular}{|c|c|c|c|c|}
\hline $\begin{array}{l}\text { ITT } \\
\text { factors }\end{array}$ & $\begin{array}{l}\text { Stage } 1 \text {-Pre- } \\
\text { assessment }\end{array}$ & Stage 2-Training & $\begin{array}{l}\text { Stage } \\
3 \text {-Teaching } \\
\text { practice }\end{array}$ & $\begin{array}{l}\text { Stage } \\
4 \text {-Co-teaching }\end{array}$ \\
\hline Adaption & & $\begin{array}{l}\text { Meanwhile, I was } \\
\text { excited because I can } \\
\text { edit an application of } \\
\text { the smartphone } \\
\text { myself. Also, it was a } \\
\text { first experience for me } \\
\text { to learn programming. } \\
\text { At the end, it had a } \\
\text { quiz which tests TAs } \\
\text { understanding toward } \\
\text { the Scratch and the } \\
\text { App inventor. It was } \\
\text { not that difficult after } \\
\text { listening to the } \\
\text { instruction of the } \\
\text { teaching leader }\end{array}$ & $\begin{array}{l}\text { In the } \\
\text { classroom, there } \\
\text { were other } \\
\text { experienced } \\
\text { TAs. I took them } \\
\text { as a reference } \\
\text { and I started to } \\
\text { imitate the way } \\
\text { they are }\end{array}$ & Nil \\
\hline Growth & & $\begin{array}{l}\text { After accomplishing a } \\
\text { set of assessment, I } \\
\text { have finally become a } \\
\text { TA }\end{array}$ & $\begin{array}{l}\text { Gradually, I } \\
\text { build up my own } \\
\text { set of practice. I } \\
\text { am confident to } \\
\text { have } \\
\text { co-teaching and } \\
\text { I can be more } \\
\text { mature to handle } \\
\text { any difficulties }\end{array}$ & $\begin{array}{l}\text { Up till now, I have } \\
\text { joined the } \\
\text { CoolThink @ JC } \\
\text { program for more } \\
\text { than a year. I have } \\
\text { participated in } \\
\text { different posts such } \\
\text { as co-teaching, } \\
\text { backup duties and } \\
\text { training program. } \\
\text { Meanwhile, I am } \\
\text { fortunate to } \\
\text { become one of the } \\
\text { supervisory TA. I } \\
\text { am delighted that I } \\
\text { can involve in } \\
\text { supervisor duties. } \\
\text { Each post provides } \\
\text { different } \\
\text { experiences for me. } \\
\text { It makes me } \\
\text { growth and it } \\
\text { broadens my } \\
\text { horizon. In } \\
\text { CoolThink@ JC, I } \\
\text { do not only learn } \\
\text { CT concept, but } \\
\text { also equip myself } \\
\text { with different } \\
\text { knowledge and } \\
\text { skills }\end{array}$ \\
\hline
\end{tabular}




\section{References}

Crutsinger, C., Pookulangara, S., Tran, G., \& Kim, D. (2004). Collaborative service learning: A winning proposition for industry and education. Journal of Family and Consumer Sciences, 93(3), $46-52$.

Furco, A. (1996). Service-learning: A balanced approach to experiential education. In Introduction to service-learning toolkit (pp. 9-13).

Kim, Y. (2001). Becoming intercultural: an integrative theory of communication and cross-cultural adaptation. Google Books.

Kim, Y., \& Ruben, B. D. (1988). Intercultural transformation: A systems theory. In Y. Kim \& W. Gudykunst (Eds.), Theories in intercultural communication (pp. 299-321). Newbury Park: Sage, cop.

Shi, X. (2006). Intercultural transformation and second language socialization. Journal of Intercultural Communication, 11.

Sigmon, R. (1994). Serving to learn, learning to serve. linking service with learning (Council for Independent Colleges Report).

Sivakumar, C., \& Kwok, C. W. (2017). Course design based on enhanced intercultural transformation theory (EI): Transforming information systems (IS) students into inventors during academic exchange. (A. 19, Ed.) Communications of the Association for Information Systems, 40.

Spencer-Oatey, H., \& Franklin, P. (2009). Intercultural interaction: a multidisciplinary approach to intercultural communication. Basingstoke: Palgrave Macmillan Ltd.

Open Access This chapter is licensed under the terms of the Creative Commons Attribution 4.0 International License (http://creativecommons.org/licenses/by/4.0/), which permits use, sharing, adaptation, distribution and reproduction in any medium or format, as long as you give appropriate credit to the original author(s) and the source, provide a link to the Creative Commons license and indicate if changes were made.

The images or other third party material in this chapter are included in the chapter's Creative Commons license, unless indicated otherwise in a credit line to the material. If material is not included in the chapter's Creative Commons license and your intended use is not permitted by statutory regulation or exceeds the permitted use, you will need to obtain permission directly from the copyright holder.

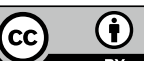

